\title{
Investigating Temperature and Nutrients as Drivers of Primary Productivity in Aquatic Environment
}

\author{
Dike Henry Ogbuagu*, Ugochukwu Obioma Nwahiri, Emmanuel Chikezie Osuebi, \\ Iheoma Ezichi Mbuka-Nwosu, Chinwe Grace Onwuagba \\ Department of Environmental Technology, Federal University of Technology, Owerri, Nigeria \\ Email: *dike.ogbuagu@futo.edu.ng
}

How to cite this paper: Ogbuagu, D. H., Nwahiri, U. O., Osuebi, E. C., Mbuka-Nwosu, I. E., \& Onwuagba, C. G. (2019). Investigating Temperature and Nutrients as Drivers of Primary Productivity in Aquatic Environment. Journal of Geoscience and Environment Protection, 7, 92-107.

https://doi.org/10.4236/gep.2019.77008

Received: May 3, 2019

Accepted: July 23, 2019

Published: July 26, 2019

Copyright $\odot 2019$ by author(s) and Scientific Research Publishing Inc. This work is licensed under the Creative Commons Attribution International License (CC BY 4.0).

http://creativecommons.org/licenses/by/4.0/

\begin{abstract}
An investigation into the relationship between temperature and the nutrients $\left(\mathrm{NO}_{3}^{-}, \mathrm{PO}_{4}^{3-}, \mathrm{SO}_{4}^{2-}\right)$ in pelagial primary productivity of the middle reaches of Otamiri River in Owerri, Southeastern Nigeria was carried out between October and November, 2018 at ten sampling points (OTP 1-OTP 10). The estimation of productivity was made with the light and dark bottle technique. Maximum yields in Gross Primary Productivity (GPP) (0.8738 $\left.\mathrm{mgCL}^{-1} \mathrm{~d}^{-1}\right)$, Net Primary Productivity (NPP) $\left(0.8513 \mathrm{mgCL}^{-1} \mathrm{~d}^{-1}\right)$, as well as Community Respiration (CR) $\left(0.1613 \mathrm{mgCL}^{-1} \mathrm{~d}^{-1}\right)$ were recorded at OTP 3 , OTP 3 and OTP 8 respectively that had more vegetation covers than in segments without cover. GPP is correlated with $\mathrm{PO}_{4}^{3-}$ ions $(\mathrm{r}=0.400), \mathrm{SO}_{4}^{2-}$ ions $(\mathrm{r}=0.418)$, and water temperature $(\mathrm{r}=0.379)(p<0.05)$, while $\mathrm{CR}$ is correlated with $\mathrm{SO}_{4}^{2-}$ ions $(\mathrm{r}=0.500)(p<0.01)$. The variability of GPP increased mildly with increasing temperature and the nutrients; with predicted regression model productivities of $0.1388,0.5621$, and $0.6066 \mathrm{mgCL}^{-1} \mathrm{~d}^{-1}$, corresponding with mean values of $28.41^{\circ} \mathrm{C}, 0.33 \mathrm{mg} / \mathrm{L}, 1.04 \mathrm{mg} / \mathrm{L}$ and 10.25 $\mathrm{mg} / \mathrm{L}$ recorded for temperature, $\mathrm{NO}_{3}^{-}, \mathrm{PO}_{4}^{3-}$, and $\mathrm{SO}_{4}^{2-}$ ions concentrations. Mean GPP was estimated to result in a comparatively low annual productivity of $188.75 \mathrm{mgCL}^{-1} \mathrm{yr}^{-1}$. Conservation and restoration of riparian vegetation covers in watershed corridors of the river for optimal driver roles were recommended.
\end{abstract}

\section{Keywords}

Primary Productivity, Otamiri River, Nutrients, Eutrophication, Riparian Vegetation 


\section{Introduction}

It is known that water quality is affected by a range of chemical, physical, biological, and biochemical attributes; some of which could provide a general indication of water pollution while others enable the direct tracking of pollution sources. According to Ogbuagu (2014), a biochemical technique that has been used to obtain indirect information about the productivity of an aquatic system is primary productivity; the production of organic compounds from aquatic $\mathrm{CO}_{2}$, mainly through photosynthesis, with chemosynthesis being much less important (Global Change, 2008).

Brandt in 1899 and 1902 first proposed that primary productivity is dependent upon the supplies of nitrate and phosphate to natural waters (Ketchum et al., 1958), even though nutrients enrichment in excess could lead to eutrophication. Our knowledge and ability to manage aquatic eutrophication has expanded greatly during the intervening three decades, as summarized in several synthetic reviews by Smith et al. (1999) and Smith $(2003,2006)$. It can now be argued that, in general, the results of nutrient over-enrichment tend to be negative, with beneficial effects being rare or accidental. In particular, eutrophication often has a strongly negative economic dimension (Segerson \& Walker, 2002). In England and Wales for example, the damage costs of freshwater eutrophication alone have been estimated at $£ 75$ - 114 million per year (Pretty et al., 2003). Similarly, the economic consequences of estuarine and coastal marine eutrophication can be very substantial, and are expected to increase over time worldwide as human populations grow and move into coastal communities.

In recent times, the demands of increasing population and associated urbanization (such as sand, mostly used for buildings and other infrastructural constructions) have placed serious pressure on the resources of the Otamiri River; one of the major rivers in southeastern Nigeria. Other ongoing anthropogenic activities include devegetation of the river corridors as reported by Ogbuagu and Okoli (2013). Elsewhere, several reports exist on the impact of anthropogenic activities on the primary productivity of aquatic ecosystems, especially those impacts on the autotrophic biota responsible for primary production in the ecosystem. For example, removal of riparian vegetation could cause direct solar irradiations to impact the temperature regime of the river and so, alter, not only the basic physical and chemical processes necessary for the survival of aquatic biota (Adams, 2010; Ogbuagu et al., 2011), but also several other physicochemical attributes of a river (Don-Pedro, 2009). Other than nutrients (Simmons et al., 2004), solar irradiation and temperature variations are reported as major limiting factors to primary productivity by phytoplankton (Vaillancourt et al., 2003). Consequently therefore, changes in primary productivity have been causally linked to temperature and the nutrient status of aquatic ecosystems for over a century. The aim of the study was to investigate the possible relationship between water temperature, nutrients availability and primary productivity regime of the Otamiri River in Owerri, Nigeria. 


\section{Materials and Methods}

\subsection{The Study Area}

The Otamiri River in Owerri serves for domestic, fisheries and artisanal sand mining uses as it courses through the Federal University of Technology, Owerri (FUTO) campus, onto the suburbs, and then to the neighbouring Rivers State, where it first confluences with the Oge-Ochie, and then Imo Rivers. The FUTO is sited in Owerri, a metropolitan city located between latitudes $05^{\circ} 29^{\prime} 06 \mathrm{~s}$ and longitude $07^{\circ} 02^{\prime} 06 \mathrm{~s}$ (Figure 1) in the southeastern part of Nigeria. The area is characterized by two major seasons; a wet season (which last from April to November) and a dry season (which last the rest of the year). Annual rainfall varies between 1500 and $2200 \mathrm{~mm}$, with mean daily minimum and maximum temperature ranges of between $19-24$ and $28^{\circ} \mathrm{C}-35^{\circ} \mathrm{C}$ respectively. Average humidity is about $80 \%$, and the vegetation of the area is semi-deciduous forest whose density has been altered by farming and deforestation.

\subsection{Sampling Locations}

Ten sampling locations were established about 50 metres apart along the course of the river within the FUTO. During sampling, in-stream sand mining activities were ongoing at several locations on the river.

\subsection{Light and Dark Bottle Experiment}

The Light and Dark Bottle technique of Gaarder and Gran (1927), as applied by Ogbuagu and Ayoade (2011) for the estimation of primary productivity was

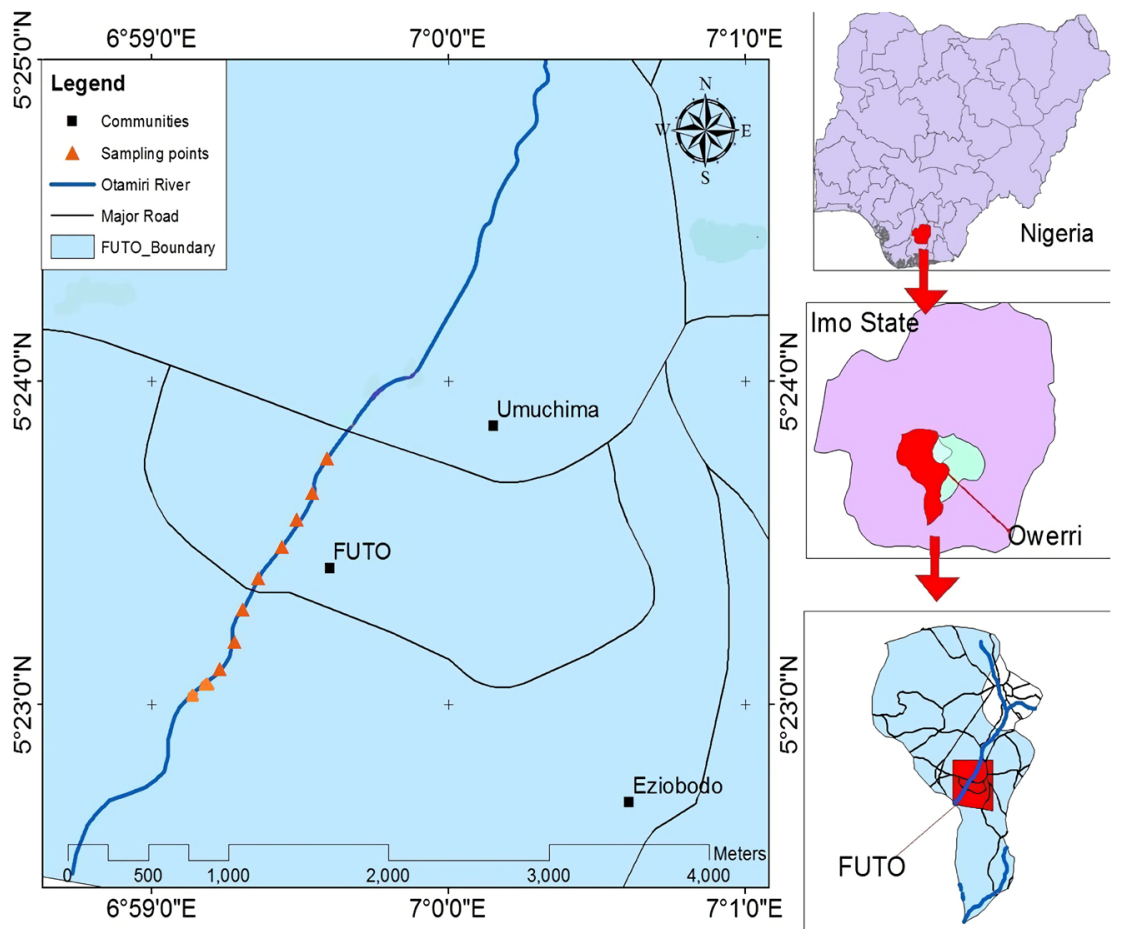

Figure 1. Map of the Otamiri River in FUTO showing the sampling points. 
used. Three identical transparent 1-litre bottles; one covered with black polythene (Dark bottle) and the others not (Light bottles) were filled with the river water and stoppered while still submerged. The dissolved oxygen content of the first light bottle $\left(\mathrm{DO}_{1}\right)$ was determined immediately with an HANNA HI 9828 $\mathrm{pH} / \mathrm{ORP} / \mathrm{EC} / \mathrm{DO}$ meter, while the other two bottles were suspended in the pelagial zone where the water had been taken with the aid of an inextensible rope for about 4 hours incubation period in a sunny afternoon (Ikenweiwe \& Otubusin, 2005). The remaining two bottles were harvested immediately after the incubation period and their dissolved $\mathrm{O}_{2}$ contents $\left(\mathrm{DO}_{\mathrm{L}} \& \mathrm{DO}_{\mathrm{D}}\right)$ determined. The experimental setup was done in replicates. Primary productivity was calculated in $\mathrm{mg}$ of $\mathrm{O}_{2}$ produced per litre of water per day according to the formula:

$$
\text { GPP }\left(\mathrm{mgO}_{2} \mathrm{~L}^{-1} \mathrm{~d}^{-1}\right)=\mathrm{NPP}\left(\mathrm{mgO}_{2} \mathrm{~L}^{-1} \mathrm{~d}^{-1}\right)+\mathrm{CR}\left(\mathrm{mgO}_{2} \mathrm{~L}^{-1} \mathrm{~d}^{-1}\right)
$$

where GPP $=$ Gross Primary Productivity, NPP $=$ Net Primary Productivity, and $\mathrm{CR}=$ Community Respiration.

The productivity results were however converted to their carbon equivalents by multiplying the $\mathrm{O}_{2}$ values by the factor 0.375 (Global Change, 2008).

\subsection{In Situ Physicochemical Measurements and Water Sample Collection}

Temperature of pelagial water was determined electrometrically in situ with the mercury-in-glass thermometer. Water samples were collected in 2 litres plastic bottles that had been severally rinsed with the river water. Samples were then transported to the laboratory in iced coolers to maintain their integrity.

\subsection{Laboratory Analysis}

Standard methods of APHA (1998) were adopted in the analysis of the nutrient ions. The cadmium reduction method was employed in the determination of $\mathrm{NO}_{3}^{-}$ions; whereby a cadmium-based reagent pillow was added into $25 \mathrm{~mL}$ of the water sample in a cuvette, shaken for 1 minute, and allowed to stand for another 5 minutes for complete reaction to occur. The absorbance and concentration in $\mathrm{mg} / \mathrm{L}$ was read at $500 \mathrm{~nm}$ wavelength using HACH DR $2010 \mathrm{UV}$-visible spectrophotometer.

The barium chloride (Turbidometric) method was adopted in the determination of $\mathrm{SO}_{4}^{2-}$ ions. The barium chloride-based powdered reagent pillow was added into $25 \mathrm{~mL}$ of water sample. The mixture was properly mixed and allowed to stand for 5 minutes for reaction to occur. The absorbance and concentration in $\mathrm{mg} / \mathrm{L}$ was read at $450 \mathrm{~nm}$ wavelength using HACH DR 2010 UV-visible spectrophotometer.

For the determination of $\mathrm{PO}_{4}^{3-}$ ions, the ascorbic acid method was adopted. Ascorbic acid based reagent powdered pillow was added into $25 \mathrm{~mL}$ of the water sample in a cuvette. The sample was allowed to stand for 2 minutes for reaction to occur. The absorbance and concentration in $\mathrm{mg} / \mathrm{L}$ was read at $890 \mathrm{~nm}$ wavelength using HACH DR 2010 UV-visible spectrophotometer. 


\subsection{Statistical Analysis}

Descriptive statistics were used to represent primary productivity variables. The Pearson correlation coefficient, was used to determine possible relationships between productivity variables and the predictors-temperature, $\mathrm{NO}_{3}^{-}, \mathrm{SO}_{4}^{2-}$, and $\mathrm{PO}_{4}^{3-}$ ions. The linear regression was used to model the values of gross primary productivity based on its linear relationship to the assumed predictors. The regression model assumes that there is a linear relationship between the dependent variable and each predictor. The relationship is described in the following formula:

$$
y_{j}=b_{0}+b_{1} x_{i l}+\cdots+b_{p} x_{i p}+e_{i}
$$

where $y_{i}$ is the value of the $i$ th case of the dependent scale variable,

$p$ is the number of predictors,

$b_{j}$ is the value of the $f^{\text {th }}$ coefficient, $j=0, \ldots, p$,

$x_{i j}$ is the value of the $i^{\text {th }}$ case of the $f^{\text {th }}$ predictor,

$e_{i}$ is the error in the observed value for the $I^{\text {th }}$ case.

The one-way ANOVA was used to determine spatial homogeneity in mean variance of the productivity and predictor variables at $p<0.05$. Mean separation was achieved with the post-hoc Duncan Multiple Range test at the $95 \%$ confidence interval.

\section{Results}

\subsection{Descriptive and Spatial Variations in Primary Productivity and Predictor Parameters}

GPP, NPP and CR varied from $0.91-2.33(1.38 \pm 0.07), 0.19-2.27(1.13 \pm 0.08)$ and $0.04-0.44(0.21 \pm 0.03) \mathrm{mgCL}^{-1} \mathrm{~d}^{-1}$ respectively. However, water temperature, $\mathrm{NO}_{3}^{-}, \mathrm{PO}_{4}^{3-}$ and $\mathrm{SO}_{4}^{2-}$ ion concentrations varied as follows: $28.07-$ $28.71(28.41 \pm 0.02)^{\circ} \mathrm{C}, 0.16-1.29(0.33 \pm 0.04) \mathrm{mg} / \mathrm{L}, 0.70-1.30(1.04 \pm 0.03)$ $\mathrm{mg} / \mathrm{L}$ and $8.00-11.40(10.25 \pm 0.19) \mathrm{mg} / \mathrm{L}$ respectively.

Highest GPP estimate of $2.33 \mathrm{mgO}_{2} \mathrm{~L}^{-1} \mathrm{~d}^{-1}\left(0.8738 \mathrm{mgCL}^{-1} \mathrm{~d}^{-1}\right)$, NPP estimate of $2.27 \mathrm{mgO}_{2} \mathrm{~L}^{-1} \mathrm{~d}^{-1}\left(0.8513 \mathrm{mgCL}^{-1} \mathrm{~d}^{-1}\right)$ and CR estimate of $0.43 \mathrm{mgO}_{2} \mathrm{~L}^{-1} \mathrm{~d}^{-1}$ $\left(0.1613 \mathrm{mgCL}^{-1} \mathrm{~d}^{-1}\right)$ were recorded at OTP 3 , OTP 3 and OTP 8 respectively (Figure 2). However, least GPP $\left(0.95 \mathrm{mgO}_{2} \mathrm{~L}^{-1} \mathrm{~d}^{-1}=0.3563 \mathrm{mgCL}^{-1} \mathrm{~d}^{-1}\right)$, NPP $\left(0.84 \mathrm{mgO}_{2} \mathrm{~L}^{-1} \mathrm{~d}^{-1}=0.3150 \mathrm{mgCL}^{-1} \mathrm{~d}^{-1}\right)$ and $\mathrm{CR}$ estimates $\left(0.06 \mathrm{mgO}_{2} \mathrm{~L}^{-1} \mathrm{~d}^{-1}=\right.$ $0.0225 \mathrm{mgCL}^{-1} \mathrm{~d}^{-1}$ ) were recorded at OTP 6 , OTP 6 and OTP 3 respectively (Figure 2).

The one-way ANOVA revealed that except in $\mathrm{NO}_{3}^{-}$ion concentrations (Sig. $\mathrm{F}$ value $=0.315$ ), all other predictor and primary productivity variables differed significantly across the sampling locations at $p<0.05$. The post-hoc Duncan Multiple Range test further revealed that in GPP, the spatial differences were between sampling locations other than SL 4 \& SL 5, SL 4 \& SL 7, SL 7 \& SL 9, SL 8 \& SL 10, SL 9 \& SL 10, SL 2 \& SL 9, SL 2 \& SL 10, SL 4 \& SL 9, and SL 2 \& SL 7 (Table 1). In NPP, the differences were between locations other than SL $2 \&$ SL 4 


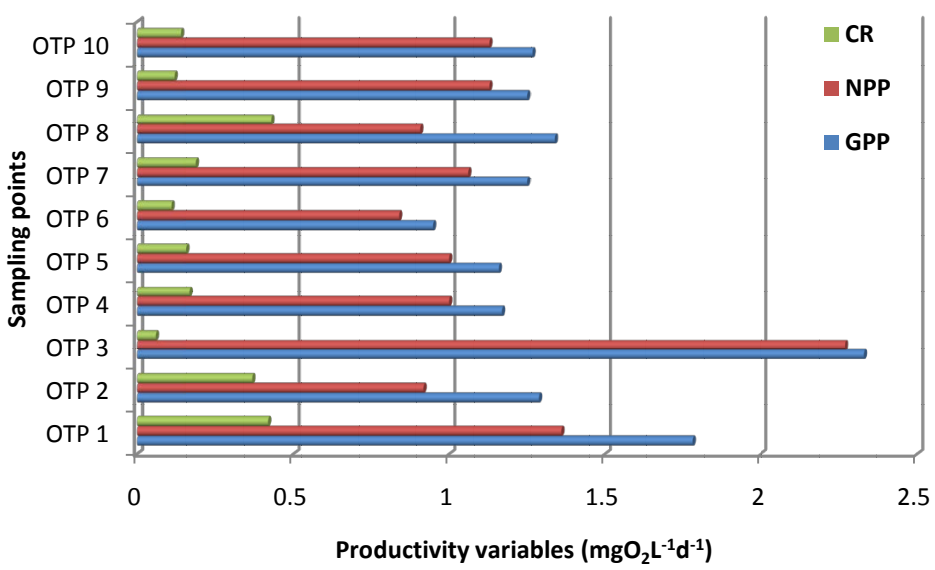

Figure 2. Spatial variations in Gross and Net Primary Productivity (GPP \& NPP) and Community Respiration (CR) of the Otamiri River in Owerri, Nigeria.

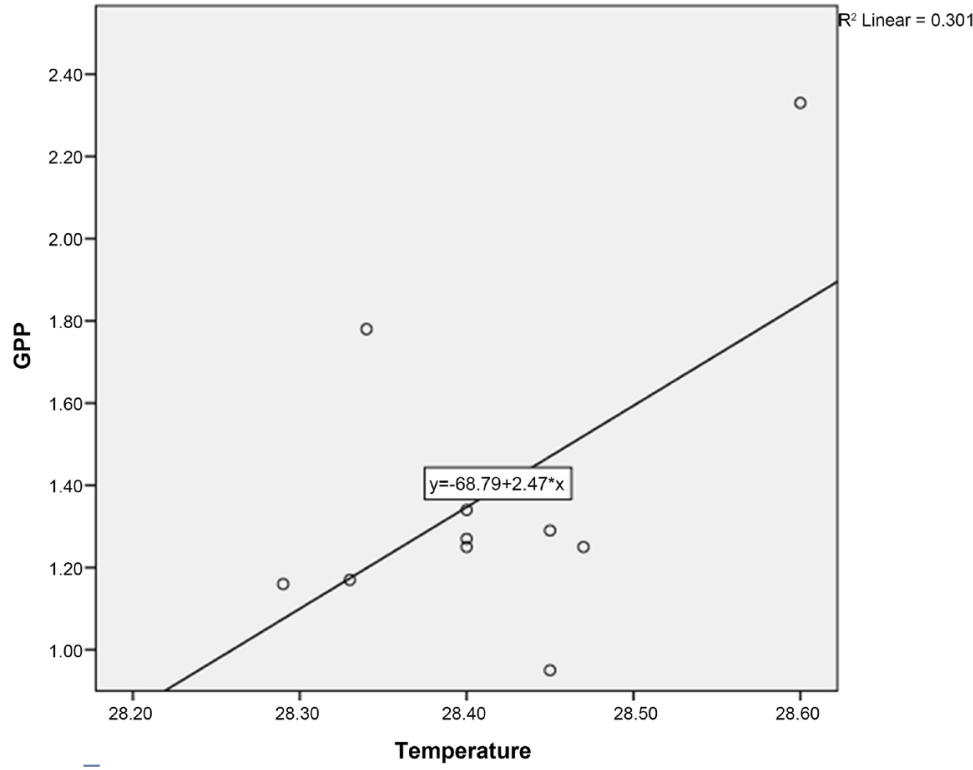

Figure 3. Linear regression scatterplot of GPP by temperature regime of the Otamiri River in Owerri.

Table 1. Mean separation in primary productivity and predictor parameters of the Otamiri River in Owerri, Nigeria.

\begin{tabular}{ccccccccccc}
\hline \multicolumn{7}{c}{ Sampling Locations $(O T P)$} \\
\hline Variables & 1 & 2 & 3 & 4 & 5 & 6 & 7 & 8 & 9 & 10 \\
\hline $\mathrm{GPP}$ & $1.7767^{\mathrm{f}}$ & $1.2900^{\mathrm{d}}$ & $2.2867^{\mathrm{a}}$ & $1.1833^{\mathrm{bc}}$ & $1.1600^{\mathrm{b}}$ & $0.9500^{\mathrm{a}}$ & $1.2500^{\mathrm{cd}}$ & $1.3400^{\mathrm{e}}$ & $1.2500^{\mathrm{cd}}$ & $1.2700^{\mathrm{de}}$ \\
$\mathrm{NPP}$ & $1.3633^{\mathrm{c}}$ & $0.9200^{\mathrm{ab}}$ & $2.2167^{\mathrm{d}}$ & $0.9867^{\mathrm{ab}}$ & $1.0000^{\mathrm{ab}}$ & $0.8400^{\mathrm{ab}}$ & $0.7600^{\mathrm{a}}$ & $0.9100^{\mathrm{ab}}$ & $1.1300^{\mathrm{bc}}$ & $1.1300^{\mathrm{bc}}$ \\
$\mathrm{CR}$ & $0.4200^{\mathrm{c}}$ & $0.3700^{\mathrm{c}}$ & $0.0700^{\mathrm{a}}$ & $0.1333^{\mathrm{a}}$ & $0.1600^{\mathrm{ab}}$ & $0.1100^{\mathrm{ab}}$ & $0.1900^{\mathrm{b}}$ & $0.4300^{\mathrm{c}}$ & $0.1200^{\mathrm{ab}}$ & $0.1400^{\mathrm{ab}}$ \\
Temperature & $28.3400^{\mathrm{a}}$ & $28.4500^{\mathrm{ab}}$ & $28.6033^{\mathrm{b}}$ & $28.3300^{\mathrm{a}}$ & $28.2900^{\mathrm{a}}$ & $28.4533^{\mathrm{ab}}$ & $28.400^{\mathrm{a}}$ & $28.4000^{\mathrm{a}}$ & $28.4700^{\mathrm{ab}}$ & $28.400^{\mathrm{a}}$ \\
$\mathrm{NO}_{3}^{-}$ & $0.6233^{\mathrm{b}}$ & $0.3000^{\mathrm{ab}}$ & $0.4000^{\mathrm{ab}}$ & $0.2000^{\mathrm{a}}$ & $0.2000^{\mathrm{a}}$ & $0.3500^{\mathrm{ab}}$ & $0.300^{\mathrm{ab}}$ & $0.2800^{\mathrm{ab}}$ & $0.2800^{\mathrm{ab}}$ & $0.3300^{\mathrm{ab}}$ \\
$\mathrm{PO}_{4}^{3-}$ & $1.1000^{\mathrm{bc}}$ & $1.000^{\mathrm{abc}}$ & $1.2000^{\mathrm{c}}$ & $1.2000^{\mathrm{c}}$ & $0.8000^{\mathrm{a}}$ & $0.900^{\mathrm{ab}}$ & $1.100^{\mathrm{bc}}$ & $1.2000^{\mathrm{c}}$ & $1.000^{\mathrm{abc}}$ & $0.9000^{\mathrm{ab}}$ \\
$\mathrm{SO}_{4}^{2-}$ & $11.000^{\mathrm{de}}$ & $11.2000^{\mathrm{e}}$ & $10.8000^{\mathrm{de}}$ & $11.000^{\mathrm{de}}$ & $8.5000^{\mathrm{a}}$ & $9.000^{\mathrm{ab}}$ & $10.5000^{\mathrm{de}}$ & $11.000^{\mathrm{de}}$ & $9.5000^{\mathrm{bc}}$ & $10.000^{\mathrm{cd}}$ \\
\hline
\end{tabular}

Values with same superscripts along same rows are not significantly difference at $p<0.05$; GPP $=$ Gross Primary Productivity, NPP $=$ Net Primary Productivity, $\mathrm{CR}=$ Community Respiration. 
\& SL 5 \& SL 6 \& SL 8, SL 2 \& SL 7, SL 1 \& SL 9 \& SL 10, and in CR, it was between locations other than SL 1 \& SL 2 \& SL 8, SL 3 \& SL 4, and SL 5 \& SL 6 \& SL 9 \& SL 10. Significant spatial differences were also observed in $\mathrm{PO}_{4}^{3-}$ ion concentrations between locations other than SL 5 and SL 1 and SL 3 and SL 4 and SL 7 and SL 8, and in $\mathrm{SO}_{4}^{2-}$ ion concentrations, it was between locations other than SL 5 and SL 1-SL 4 and SL 7-SL 10 (Table 1).

\subsection{Relationships between Primary Productivity and Predictor Variables}

There were significant Pearson's correlationships (r) existing between the primary productivity parameters and predictor variables (Table 2). At $p<0.05$, GPP correlated positively with $\mathrm{PO}_{4}^{3-} \quad(\mathrm{r}=0.400), \mathrm{SO}_{4}^{2-} \quad(\mathrm{r}=0.418)$ and water temperature $(r=0.379)$, and NPP correlated with temperature $(r=0.375)$. However, at $p<0.01$, CR correlated with $\mathrm{SO}_{4}^{2-}$ ions $(\mathrm{r}=0.500)$. The linear regression scatterplot of GPP by temperature shows that variability of GPP increased with increasing temperature (Figure 3). However, the significant value of the F-statistics (0.101) indicates that the variation explained by the model could be due to chance at $p<0.05$. The Regression Sum of Square (0.420) and Residual Sum of Square (0.976), which are unequal, as well as the coefficient of determination $\left(\mathrm{R}^{2}\right.$ $=0.301$ ) all indicate that less than half the variation in GPP could be explained by the model. The multiple correlation coefficient, $R$, is average ( $R=0.548)$, indicating an average relationship.

The model further shows that:

$$
y=-68.79+(2.47) x
$$

i.e. the expected yield in GPP $=-68.79+2.47 \times$ temperature

The residual, which is the difference between the observed and model-predicted values of the dependent variable (GPP) (Figure 4) shows the shape of the histogram approximately following the shape of the normal curve. The P-P plotted residuals (Figure 5) followed the prescribed $45^{\circ}$ line; indicating that neither the histogram nor the P-P plot violated the normality assumption. The plot of residuals

Table 2. Correlation coefficient (r) matrix between Primary Productivity and Predictor variables in the Otamiri River, Owerri, Nigeria.

\begin{tabular}{cccccc}
\hline & $\mathrm{GPP}$ & $\mathrm{NPP}$ & $\mathrm{CR}$ & $\mathrm{NO}_{3}^{-}$ & $\mathrm{PO}_{4}^{3-}$ \\
\hline $\mathrm{NPP}$ & $0.883^{* *}$ & & & & \\
$\mathrm{CR}$ & 0.057 & -0.214 & & & \\
$\mathrm{NO}_{3}^{-}$ & 0.349 & 0.250 & 0.226 & & \\
$\mathrm{PO}_{4}^{3-}$ & $0.400^{*}$ & 0.216 & 0.084 & 0.111 & \\
$\mathrm{SO}_{4}^{2-}$ & $0.418^{*}$ & 0.189 & $0.500^{* *}$ & 0.212 & $0.526^{* *}$ \\
$\mathrm{Temp}^{*}$ & $0.379^{*}$ & $0.375^{*}$ & -0.129 & 0.100 & 0.144 \\
\hline
\end{tabular}

* = significant at $p<0.05,{ }^{*}=$ significant at $0.01, \mathrm{GPP}=$ Gross Primary Productivity, NPP $=$ Net Primary Productivity, $\mathrm{CR}=$ Community Respiration, $\mathrm{Temp}=$ Water temperature. 


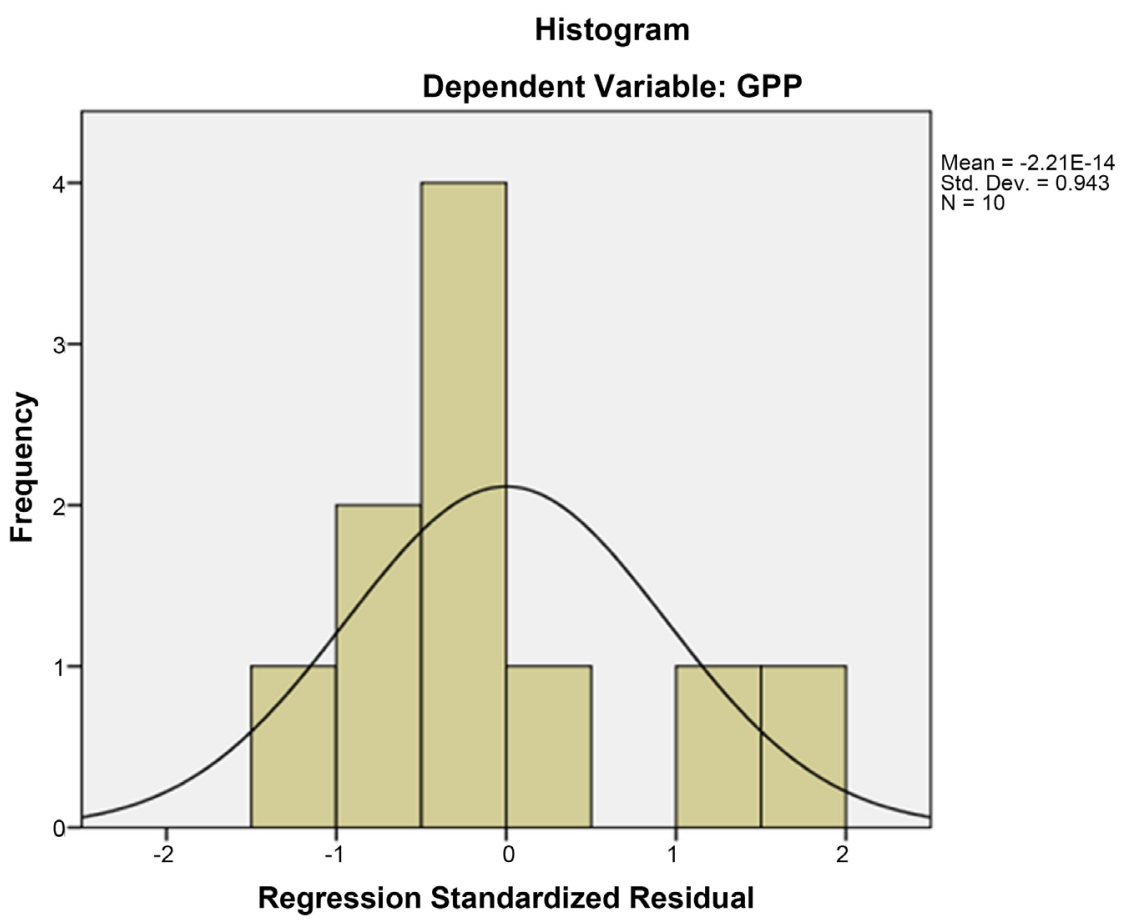

Figure 4. Regression Standardized Residual plot of Normality of Error Term in GPP by temperature regime of Otamiri River in Owerri.

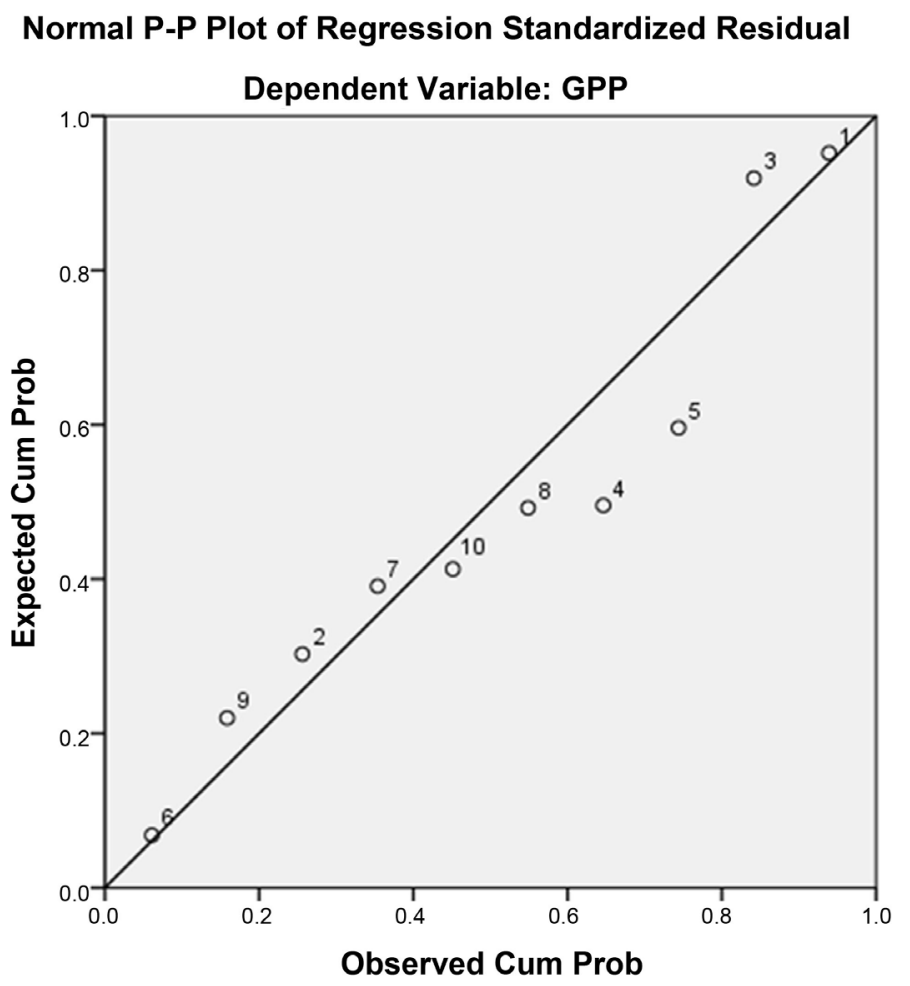

Figure 5. P-P plot of Normality of Error Term in GPP of the Otamiri River in Owerri.

by the predicted values reveals that the variance of the errors increased with increasing predicted GPP. 
Figure 6 shows the linear regression scatterplot of GPP by $\mathrm{NO}_{3}^{-}$, and reveals that the variability of GPP increased with increasing nitrate ion concentrations. However, the sig. value of the F-statistics (0.125) indicates that the variation explained by the model could be merely due to chance at $p<0.05$. The multiple correlation coefficient, $R$, is average $(R=0.518)$, indicating an average relationship; even though the coefficient of determination $\left(R^{2}=0.268\right)$, and the Regression Sum of Squares (0.375) and Residual Sum of Squares (1.021), which are unequal all indicate that less than $1 / 1$ of the variation in GPP could be explained by the model.

The model shows that:

$$
y=0.4+(3.33) x
$$

i.e. the expected yield in GPP $=0.4+3.33 \times$ Nitrate ions

The residual (Figure 7) shows a histogram approximately similar to the shape of the normal curve.

The outcome linear regression scatterplot of GPP by $\mathrm{PO}_{4}^{3-}$ ion concentrations reveals that the variability of GPP increased with increasing phosphate ions (Figure 8). The sig. value of the F-statistics (0.120) indicates that the variation explained by the model could, again be due to chance at the $95 \%$ confidence limit. The multiple correlation coefficient, which is average $(\mathrm{R}=0.524)$, indicates a strong relationship, even though the coefficient of determination $\left(R^{2}=0.274\right)$, as well as the Regression (0.383) and Residual Sums of Squares (1.013) which are unequal, all indicate that much less than $1 / 2$ of the variation in GPP could be explained by the regression model.

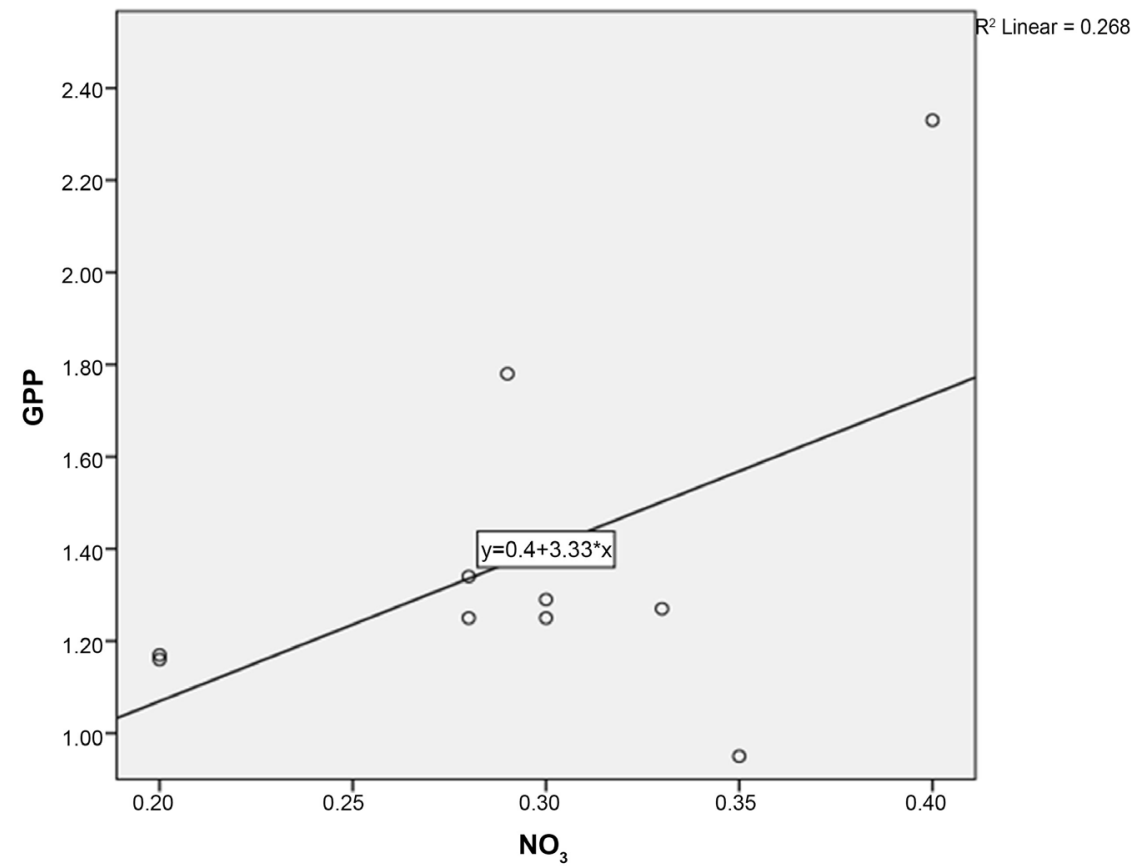

Figure 6. Linear regression scatterplot of GPP by $\mathrm{NO}_{3}^{-}$ion concentrations of the Otamiri River in Owerri. 


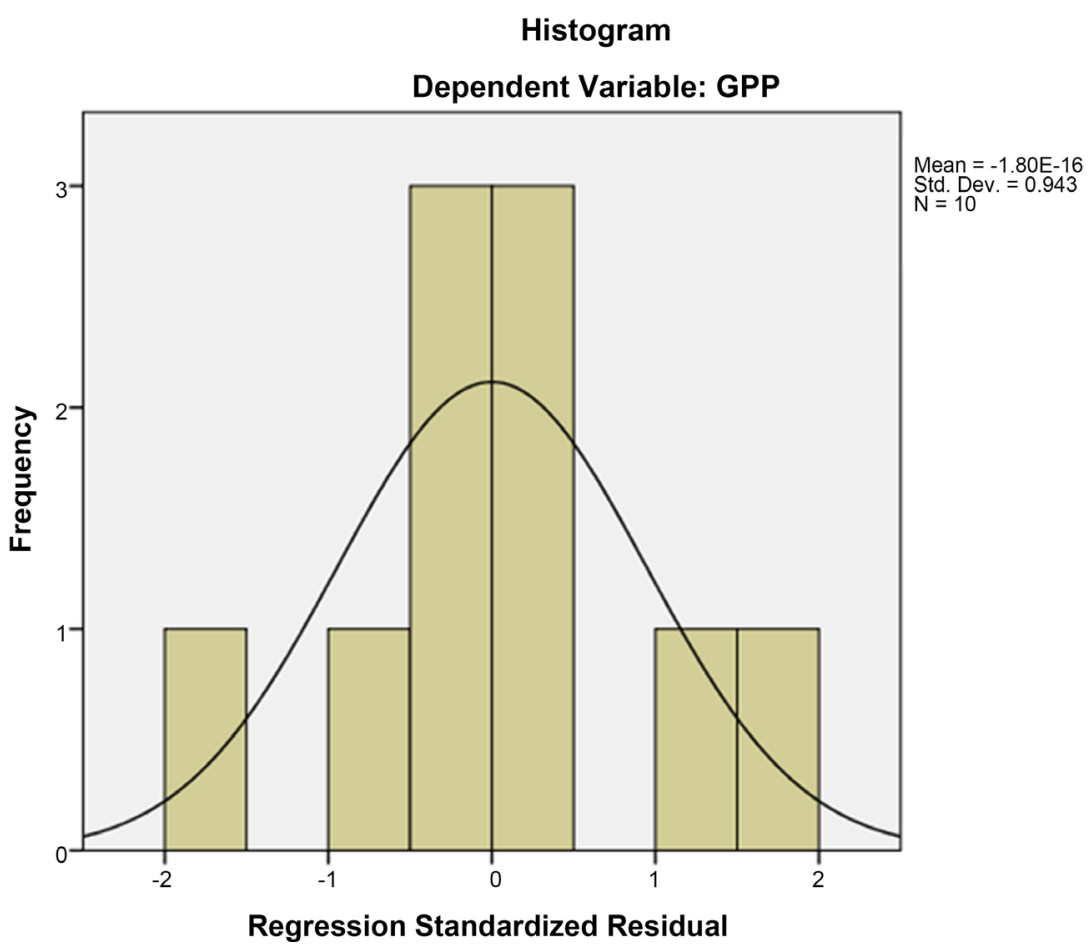

Figure 7. Regression Standardized Residual plot of Normality of Error Term in GPP by $\mathrm{NO}_{3}^{-}$ion concentrations of Otamiri River in Owerri.

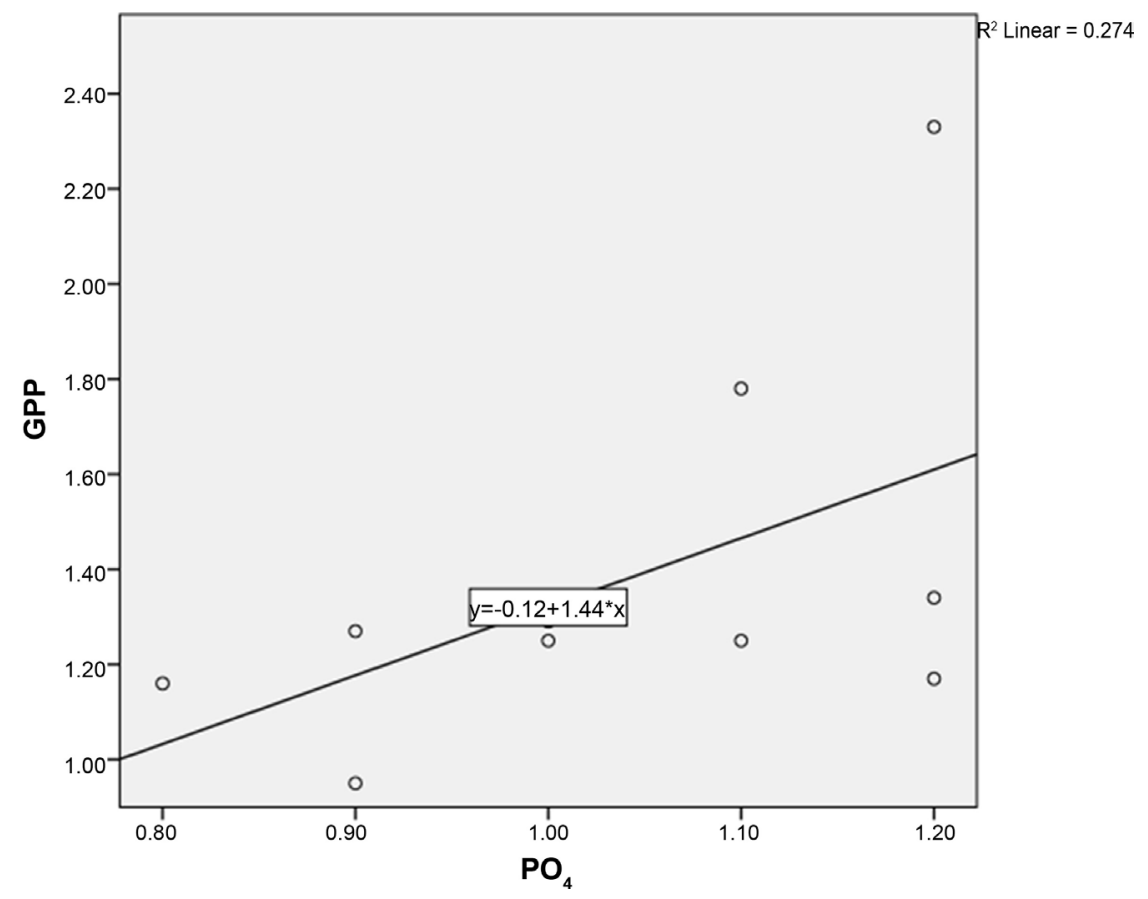

Figure 8. Linear regression scatterplot of GPP by $\mathrm{PO}_{4}^{3-}$ ion concentrations of the Otamiri River in Owerri.

The model further shows that:

$$
y=0.12+(1.44) x
$$


i.e. the expected yield in GPP $=0.12+1.44 \times$ phosphate ions

Again, the difference between the observed and model-predicted values of the dependent variable (GPP) (residual) (Figure 9) reveals the shape of the histogram approximately following the shape of the normal curve.

For $\mathrm{SO}_{4}^{2-}$, the linear regression scatterplot shows that the variability of GPP increased with increasing sulphate ion concentrations (Figure 10). Again, the significant value of the F-statistics $(0.178)$ indicates that the variation explained by the model could be due to chance at $p<0.05$. The multiple correlation coefficient, $\mathrm{R}$ is less than average $(\mathrm{R}=0.462)$, indicating a weak relationship, even as the coefficient of determination $\left(R^{2}=0.214\right)$ and Regression $(0.298)$ and Residual sums of squares (1.097) which are unequal indicate that less than $1 / 2$ of the variation in GPP could be explained by the model.

The model further shows that:

$$
y=0.58+(0.19) x
$$

i.e. the expected yield in GPP $=0.58+0.19 \times$ sulphate ions

The residual shows the shape of the histogram not following the shape of the normal curve (Figure 11). This histogram is therefore not acceptably close to the normal curve, and therefore indicates skewness.

\section{Discussion}

The current study revealed that primary productivity varied slightly across the

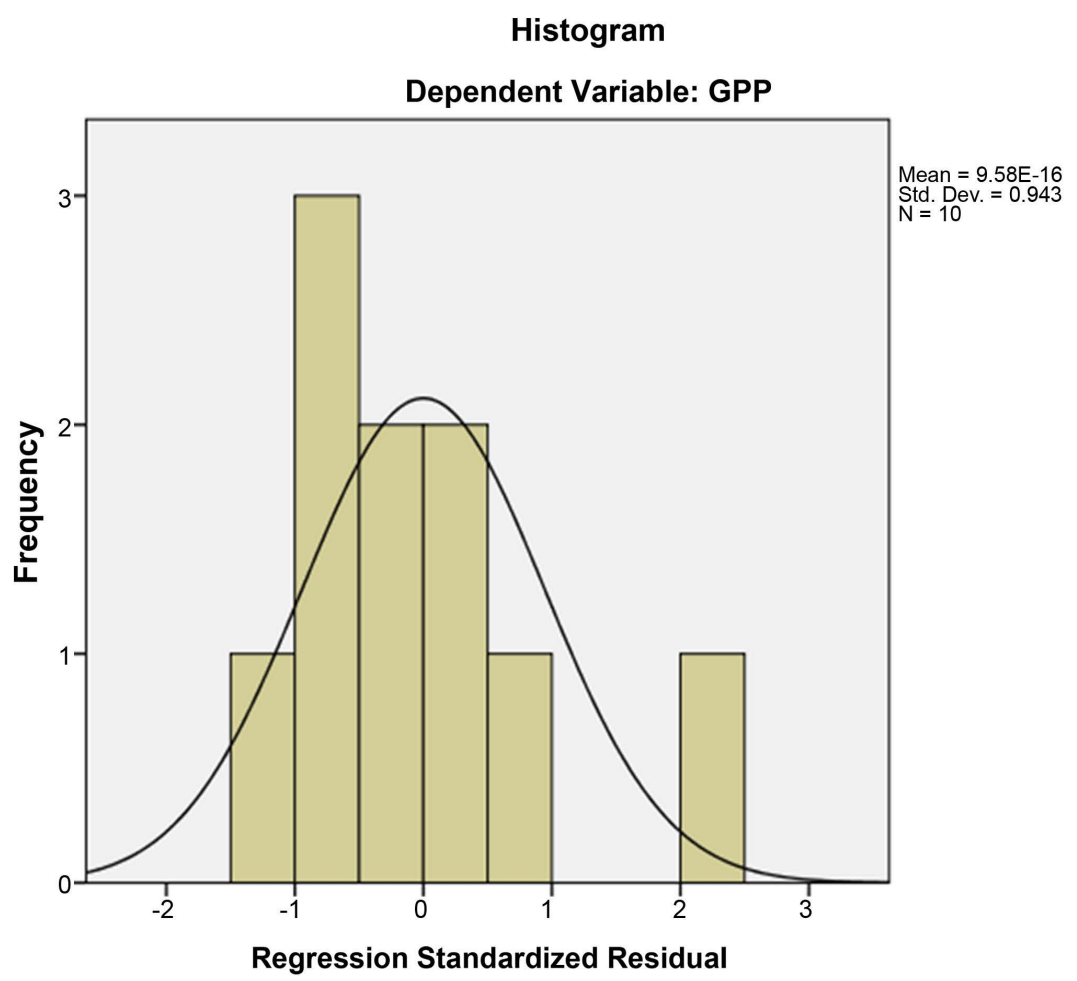

Figure 9. Regression Standardized Residual plot of Normality of Error Term in GPP by $\mathrm{PO}_{4}^{3-}$ ion concentrations of Otamiri River in Owerri. 


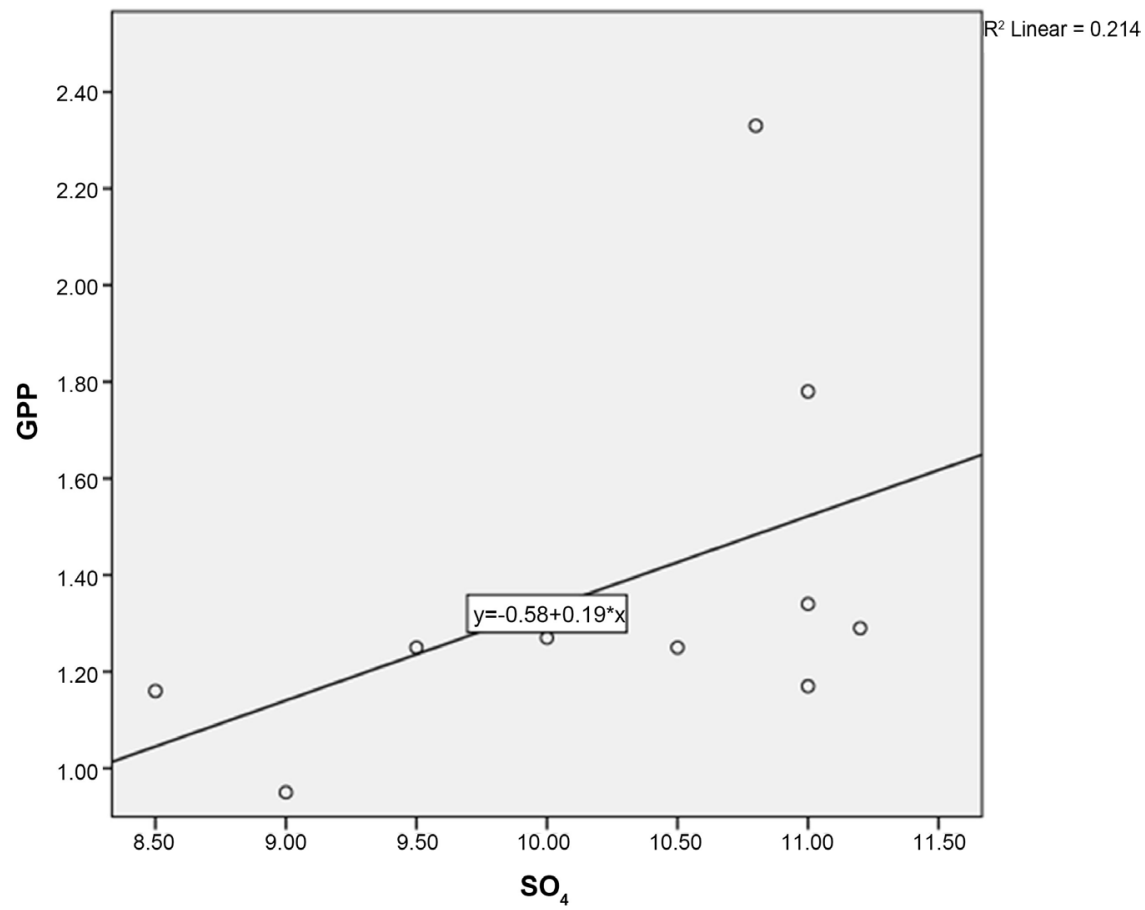

Figure 10. Linear regression scatterplot of GPP by $\mathrm{SO}_{4}^{2-}$ ion concentrations of the Otamiri River in Owerri.

\section{Histogram}

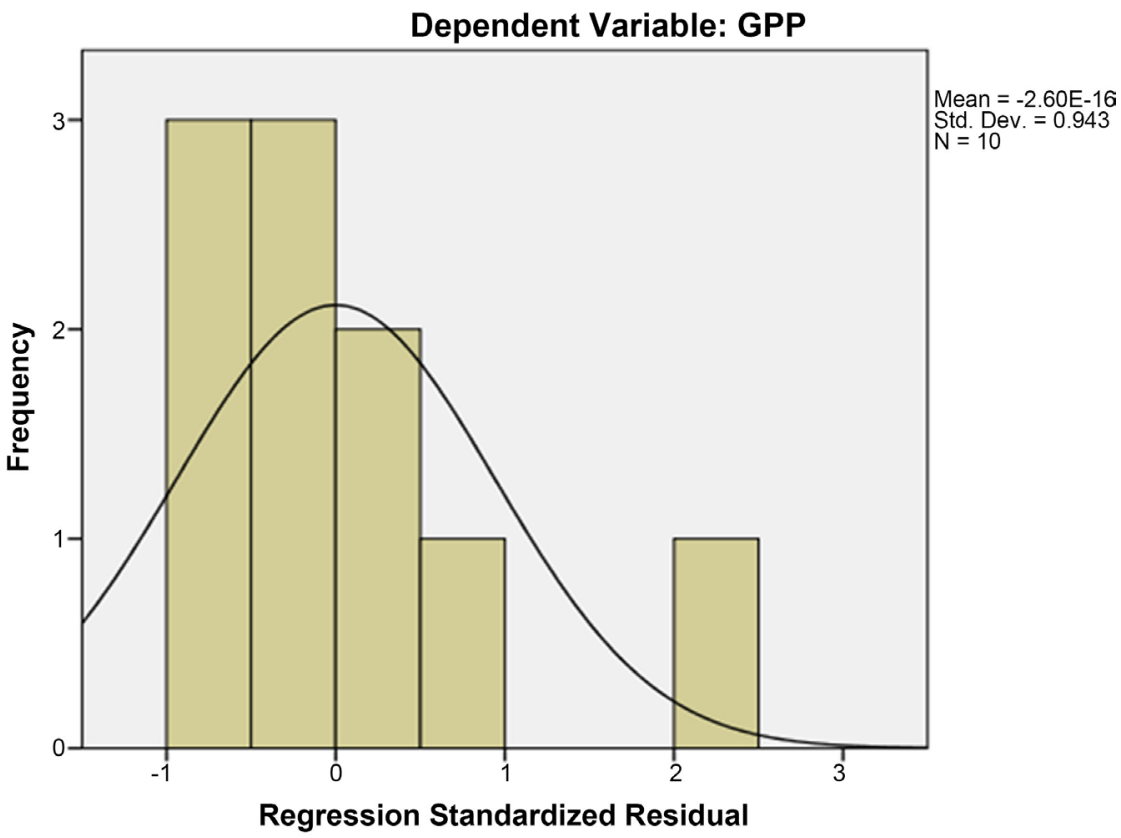

Figure 11. Regression Standardized Residual plot of Normality of Error Term in GPP by $\mathrm{SO}_{4}^{2-}$ ion concentrations of Otamiri River in Owerri.

sampling points. For example, point OTP 3 recorded the highest productivity and OTP 8 , the highest community respiration estimates; indicating that the respective points were most productive and inhabited by the most active aerobic 
autotrophic microorganisms. Net primary productivity followed the same spatial trend as gross primary productivity. OTP 6 that recorded the least productivity had fewer riparian vegetation cover than the rest sampling points during this period. A negative impact of removal of riparian vegetation on primary productivity of a freshwater aquatic ecosystem had been explored by Ogbuagu and Okoli (2013); wherein they established that the removal of riparian covers exposed some segments of the Otamiri River to direct solar irradiation and consequent excessive and unfavourable temperature elevations. The current study contradicts that of Ogbuagu and Okoli (2013) in its revelation that that productivity increased with increasing temperature regime of the river. However, this current observation is in concordance with the work of Truitt (2006) in four ponds, wherein he observed that as the temperature of the ponds rose, there was more dissolved oxygen (leading to higher productivity), thus allowing the oxygen to be saturated even more. A fact that is underscored here is that there exist is temperature threshold for the enhancement of this biochemical process, above which the productivity process will be hampered. Accordingly, the UNEP GEMS (2006) states that temperature affects the speed of chemical reactions, the rate of photosynthesis (primary productivity) by algae and aquatic plants, the rate of metabolism in organisms, as well as the interactions of pollutants, parasites and other pathogens with aquatic residents. It also influences the solubility of dissolved oxygen (which was used to estimate productivity in the current study) and other materials (e.g. $\mathrm{CO}_{2}$ ) required for photosynthesis in water column.

Though higher temperature regimes in water column would reduce the availability of the all-important dissolved $\mathrm{CO}_{2}$ necessary for primary production, the linear regression model output in the current study indicates that an increase by the recorded mean temperature value would result in about $0.1388 \mathrm{mgCL}^{-1} \mathrm{~d}^{-1}$ increases in productivity of the segment of the river.

The mean Gross Primary Productivity (GPP) recorded in the present study $\left(0.1379 \pm 0.02 \mathrm{mgO}_{2} \mathrm{~L}^{-1} \mathrm{~d}^{-1}\right)$ is low, especially when compared with the works of Samaan (1971) in Nasser Lake (4.405 $\mathrm{gO}_{2} \mathrm{~m}^{-2} \mathrm{~d}^{-1}$ ), Mbagwu and Adeniji (1994) in Mariut Lake (4.481 $\mathrm{gO}_{2} \mathrm{~m}^{-2} \mathrm{~d}^{-1}$ ) and Ikenweiwe and Otubusin (2005) in Oyan Lake, all in Nigeria $\left(3.9 \mathrm{gO}_{2} \mathrm{~m}^{-2} \mathrm{~d}^{-1}\right)$. However, it was higher than the mean value of $0.00125 \mathrm{gO}_{2} \mathrm{~m}^{-2} \mathrm{~d}^{-1}$ recorded by Adeniji (1980) in Bakolori Lake, Sokoto State and $0.041 \mathrm{gO}_{2} \mathrm{~m}^{-2} \mathrm{~d}^{-1}$ recorded by Adeniji (1990) in Asa Lake in Ilorin, all in Nigeria. This low productivity would correspond with low phytoplankton abundance in the study, which may have in turn been created by intense ongoing in-stream sand mining activities. Ogbuagu and Samuel (2014) had observed that in-stream sand mining activity could exert significant negative impacts on the ecodynamics of the river. The current study therefore would result in a low annual productivity estimate of about $503.335 \mathrm{mgO}_{2} \mathrm{~L}^{-1} \mathrm{yr}^{-1}\left(=188.751 \mathrm{mgCL}^{-1} \mathrm{~d}^{-1}\right)$. However, this productivity was unequal spatially, with sampling location 3 recording highest GPP due to its relatively pristine disposition.

The low nutrient levels recorded in this study, especially of nitrate and phosphate ions, as also observed by Guildford and Hecky (2000) elsewhere, acted as 
productivity-limiting factors that exerted influences on photosynthesis by the autotrophs. Direct enhancing influences of the nutrients on primary productivity have been noted by Ogbuagu et al. (2011) in Imo River in Etche, Nigeria and Simmons et al. (2004) in an acid mine drainage treatment pond in the United States. Accordingly, Net Primary Productivity (NPP) and Community Respiration (CR) values closely followed the trend of GPP. This indicates a stable community composition of autotrophs utilizing part of the gross production.

Both nitrate, phosphate and sulphate ions exerted positive influences on primary productivity in this work. Given the mean values of $\mathrm{NO}_{3}^{-}, \mathrm{PO}_{4}^{3-}$, and $\mathrm{SO}_{4}^{2-}$ ion concentrations, the regression models in the current work would result in gross productivity estimates of about $0.5621,0.6066$, and $0.9478 \mathrm{mgCL}^{-1} \mathrm{~d}^{-1}$ respectively. Several other studies, including that of Guildford and Hecky (2000) have observed that phosphorus (as in phosphates) and nitrogen (as in nitrates) loadings specifically are primary causes of nutrient enrichment (eutrophication) of inland waters, which could lead to increased primary production. Conversely, Truitt (2006) had also observed that as the variables contributing to primary productivity (DO, nitrogen, and phosphorus) increased, the gross and net primary productivity decreased uniformly.

\section{Summary/Conclusion}

Yields in primary productivity were generally low, and segments of the river with vegetation covers had higher yields than segments without cover. Productivity was mildly limited by temperature and nutrients availability.

\section{Recommendations}

The following recommendations are made:

- Conservation and restoration of riparian covers as watershed management approaches should be embarked upon on river system;

- Monitoring of anthropogenic activities, such as in-stream sand mining and discharge of untreated domestic wastes should be carried out so as to create reduction in aquatic pollution;

- Possible improvement of productivity of the river through iron fertilization trials should be explored.

\section{Acknowledgements}

We acknowledge the assistance of Transcontinental Petrotech (Nigeria) Limited in supply of the in situ analytical equipment used in this study.

\section{Conflicts of Interest}

The authors declare no conflicts of interest regarding the publication of this paper.

\section{References}

Adams, S. M. (2010). Establishing Causality between Environmental Stressors and Effects 
on Aquatic Ecosystems. Human Ecology and Risk Assessment, 9, 17-35. https://doi.org/10.1080/713609850

Adeniji, H. A. (1980). Vertical Distribution of Pelagic Primary Production in Kainji Lake. K.L.R.I. Annual Report, 23-27.

Adeniji, H. A. (1990). Limnology and Biological Production in the Pelagic Zone of Jebba Lake, Nigeria. Ph.D. Thesis, Nigeria: University of Ibadan.

American Public Health Association (APHA) (1998). Standard Methods for the Examination of Water and Wastewater (20th ed.). Washington DC: APHA/AWWA/WEF.

Don-Pedro, K. N. (2009). Man and the Environmental Crisis. In K. N. Don-Pedro, A. A. Otitoloju, \& P. O. Don-Pedro (Eds.). Lagos, Nigeria: Cheers Book Series.

Gaarder, T., \& Gran, H. H. (1927). Investigations of the Production of Phytoplankton in the Oslo Fjord. Rapports et procès-verbaux des réunions/Conseil international pour l'exploration de la mer, 42, 1-48.

Global Change (2008). The Flow of Energy: Primary Production to Higher Trophic Levels. The Reagents of the University of Michigan. http://www.globalchange.umich.edu

Guildford, S. J., \& Hecky, R. E. (2000). Total Nitrogen, Total Phosphorus, and Nutrient Limitation in Lakes and Oceans: Is There a Common Relationship? Limnology and Oceanography, 45, 1213-1223. https://doi.org/10.4319/lo.2000.45.6.1213

Ikenweiwe, N. B., \& Otubusin, S. O. (2005). An Evaluation of the Pelagial Primary Productivity and Potential Fish Yield of Oyan Lake, South Western Nigeria. The Zoologist, 3, 46-57.

Ketchum, B. H., Ryther, J. H., Yentsch, C. S. et al. (1958). Productivity in Relation to Nutrients. Conseil Permanent International pour l'exploration de la Mer, 144, 132-140.

Mbagwu, I. E., \& Adeniji, H. A. (1994). A Review of the Studies on the Limnology of Kainji Lake, Nigeria (p. 10). New Bussa, Nigeria: The Nigerian/German (ETZ) Kainji Lake Fisheries Promotion Project.

Ogbuagu, D. H. (2014). Physico-Chemical Characteristics, Plankton and Macrobenthos of Imo River in Etche Local Government Area, Rivers State, Nigeria. Ph.D. Thesis, Ibadan, Oyo, Nigeria: University of Ibadan.

Ogbuagu, D. H., \& Ayoade, A. A. (2011). Estimation of Primary Production along Gradients of the Middle Course of Imo River in Etche, Nigeria. International Journal of Biosciences, 1, 68-73. http://www.innspub.net

Ogbuagu, D. H., \& Okoli, C. G. (2013). What Influence Does Removal of Riparian Vegetation Have on Primary Productivity of a River. Central European Journal of Experimental Biology, 2, 5-12.

Ogbuagu, D. H., \& Samuel, C. B. (2014). Accumulation and Recovery Capacity of Heavy Metals in Sand Mine Ponds of the Otamiri River in Owerri, Nigeria. Ambiente \& Agua: An Interdesciplinary Journal of Applied Science, 9, 46-54. http://www.ambi-agua.net https://doi.org/10.4136/ambi-agua.1226

Ogbuagu, D. H., Chukwuocha, N. A. C., Okoli, C. G., \& Njoku-Tony, R. F. (2011). Physicochemical Gradients and in Situ Yields in Pelagial Primary Production of the Middle Reaches of Imo River in Etche, South-Eastern Nigeria. Journal of Ecology and the Natural Environment, 3, 47-53.

Pretty, J. N., Mason, C. F., Nedwell, D. B., Hine, R. E., Leaf, S., \& Dils, R. (2003). Environmental Costs of Freshwater Eutrophication in England and Wales. Environmental Science \& Technology, 37, 201-208. https://doi.org/10.1021/es020793k

Samaan, A. A. (1971). Report on the Trip on Lake Nasser to Investigate Its Primary Pro- 
duction during March 1971. Alexander Institute of Oceanography and Fisheries.

Segerson, K., \& Walker, D. (2002). Nutrient Pollution: An Economic Perspective. Estuaries, 25, 797-808. https://doi.org/10.1007/BF02804906

Simmons, J. A., Long, J. M., \& Ray, J. W. (2004). What Limits the Productivity of Acid Mine Drainage Treatment Ponds? Mine Water and the Environment, 23, 44-53. https://doi.org/10.1007/s10230-004-0035-1

Smith, V. H. (2003). Eutrophication of Freshwater and Marine Ecosystems: A Global Problem. Environmental Science and Pollution Research, 10, 126-139. https://doi.org/10.1065/espr2002.12.142

Smith, V. H. (2006). Using Primary Productivity as an Index of Coastal Eutrophication: The Units of Measurement Matter. Journal of Plankton Research, 29, 1-6. https://doi.org/10.1093/plankt/fbl061

Smith, V. H., Tilman, G. D., \& Nekola, J. C. (1999). Eutrophication: Impacts of Excess Nutrient Inputs on Freshwater, Marine, and Terrestrial Ecosystems. Environmental Pollution, 100, 179-196. https://doi.org/10.1016/S0269-7491(99)00091-3

Truitt, B. E. (2006). The Effects of Nitrogen and Phosphorus on Eutrophication and Aquatic Primary Productivity. California Science Center, Los Angeles, CA: California State Science Fair 2006.

United Nations Environmental Programme Global Environment Monitoring System (UNEP GEMS)/Water Programme (2006). Water Quality for Ecosystem and Human Health (132 p). Burlington, Ontario: UNEP-GEM System/Water Programme.

Vaillancourt, R. D., Marra, J., Barber, R. T., \& Smith Jr., W. O. (2003). Primary Productivity and in Situ Quantum Yields in the Ross Sea and Pacific Sector of the Antarctic Circumpolar Current. Deep Sea Research Part II: Topical Studies in Oceanography, 55, 559-578. https://doi.org/10.1016/S0967-0645(02)00584-2 